\title{
KEMAMPUAN MEMBACAKAN TEKS BERITA PADA SISWA KELAS VIII 1 SMP NEGERI 3 KOTA BENGKULU TAHUN AJARAN 2016/2017
}

\author{
Jenny Yandryati ${ }^{1}$, Gumono ${ }^{2}$, dan Agus Joko Purwadi ${ }^{3}$ \\ ${ }^{1,2,3}$ Program Studi Pendidikan Bahasa dan Sastra Indonesia \\ Jurusan Pendidikan Bahasa dan Seni \\ FKIP Universitas Bengkulu \\ jenny.yandryanti@yahoo.com
}

\begin{abstract}
Abstrak
Tujuan penelitian ini untuk mengetahui kemampuan membaca teks berita pada siswa kelas VIII 1 SMP Negeri 3 Kota Bengkulu. Metode yang digunakan dalam penelitian ini adalah metode deskriptif dengan pendekatan kuantitatif. Populasi dalam penelitian ini adalah semua siswa kelas VIII SMP Negeri 3 Kota Bengkulu yang berjumlah 140 orang siswa dari empat kelas dengan 75 orang siswa laki-laki dan 76 orang siswa perempuan. penelitian ini menggunakan teknik simpel random sampling mengambil orang-orang terpilih betul oleh peneliti menurut ciri-ciri spesifik yang dimiliki sampel, peneliti mengambil $14 \%$ dari jumlah populasi yaitu 20 orang siswa. Teknik pengumpulan data dilakukan dengan teknik observasi dan tes membaca nyaring. Analisis data yang digunakan dalam penelitian ini statistik sederhana. Hasil penelitian ini menunjukkan bahwa, rata-rata kemampuan membacakan teks berita siswa kelas VIII 1 SMP Negeri 3 Kota Bengkulu adalah 55,2 (kurang).
\end{abstract}

\section{Kata kunci: kemampuan, membacakan, teks berita}

\begin{abstract}
The purpose of this study to determine the ability to read news texts on students of class VIII 1 SMP Negeri 3 Kota Bengkulu. The method used in this research is descriptive method with quantitative approach. The population in this study were all students of class VIII SMP Negeri 3 Kota Bengkulu which amounted to 140 students from four classes with 75 male students and 76 female students. This research uses simple random sampling technique to take the chosen people correct by the researcher according to the specific characteristics of the sample, the researchers took $14 \%$ of the total population of 20 students. Technique of data collecting is done by observation technique and loud reading test. The data analysis used in this study is simple statistic. The results of this study indicate that, the average ability to read the news text of students of grade VIII 1 SMP Negeri 3 Kota Bengkulu is 55.2 (less).
\end{abstract}

Keywords: ability, read, news tex

\section{PENDAHULUAN}

Pembelajaran Bahasa Indonesia diarahkan dapat meningkatkan kemampuan siswa untuk berkomonikasi dalam Bahasa Indonesia, baik lisan maupun tulis serta menimbulkan penghargaan terhadap hasil cipta manusia.
Dalam pembelajaran Bahasa Indonesia ada empat aspek keterampilan berbahasa yaitu keterampilan membaca, menyimak, berbicara dan menulis. Keterampilan membaca merupakan salah satu aspek keterampilan berbahasa yang harus dikuasai oleh siswa. Selain keterampilan 
menyimak, berbicara, dan menulis, keempat itu merupakan kesatuan yang tidak dapat dipisahkan.

Nurhadi

(2016:2-4)

mengungkapkan bahwa ada beragam pengertian membaca. Pengertian secara sempit, membaca adalah kegiatan memahami makna yang terdapat dalam tulisan. Sementara dalam pengertian luas, membaca adalah proses pengolahan bacaan secara kritis-kreatif yang dilakukan pembaca untuk memperoleh pemahaman menyeluruh tentang bacaan itu, yang diikuti oleh penilaian terhadap keadaan, nilai, fungsi, dan dampak bacaan itu. Adapun Rahim (2015:2) mengemukakan bahwa membaca pada hakikatnya adalah suatu yang rumit yang melibatkan banyak hal, tidak hanya sekedar melafalkan tulisan, tetapi juga melibatkan aktivitas visual, berfikir, psikolinguistik, dan metakognitif. Sebagai proses visual membaca merupakan proses menerjemahkan simbol tulis (huruf) ke dalam kata-kata lisan.

Secara umum tujuan orang membaca adalah memperoleh informasi dari suatu teks tulis; sedangkan secara khusus, berdasarkan jenis informasi, ada tiga tujuan membaca, yaitu tujuan membaca referensial, tujuan membaca intelektual, dan tujuan membaca untuk kesenangan. Tujuan membaca yang berbeda-beda mensyaratkan penggunaan teknik-teknik membaca yang berbedabeda pula. Penyesuaian teknik membaca dengan tujuan membaca dapat mengefisienkan proses membaca tersebut.

Salah satu jenis membaca, yaitu membaca nyaring. Membaca nyaring sering disebut dengan istilah membaca bersuara atau membaca lisan (reading out loud; oral reading; reading aloud). Suyatno (2004:33) mengemukakan bahwa membaca nyaring biasanya dilakukan dengan vokalisasi. Selain berfungsi sebagai pemahaman untuk diri sendiri, membaca bersuara berfungsi sebagai pemahaman untuk orang lain. Membaca nyaring memiliki peranan dalam proses belajar siswa.

Nadimah (2011:6) mengemukakan bahwa kegiatan membaca nyaring dapat meningkatkan keterampilan siswa dalam memahami bacaan secara lebih baik serta mengingat secara terus-menerus pengungkapan kata-kata, sehingga memperkaya kosa katanya. Pada tataran lanjut, kegunaan keterampilan membaca nyaring dalam kehidupan sehari-hari dapat dilihat pada seorang penyiar radio, pembaca berita televisi, pendeta, ulama, atau aktor. Dengan demikian, jika keterampilan membaca nyaring ini benarbenar dikuasai, siswa akan mendapatkan banyak manfaat di kemudian hari.

Salah satu jenis membaca nyaring ada membaca berita. Kegiatan membaca tersebut dapat membangun pengetahuan dan pengalaman terutama keterampilan berbahasa yang penting untuk perkembangan siswa dan berguna untuk mendukung kegiatan belajar. Namun, ada beberapa yang harus diperhatikan dalam membaca berita. Somad (2007:10) menngemukakan bahawa hal yang harus diperhatikan agar dapat membaca teks berita dengan baik yaitu; intonasi, pelafalan, volume suara, penjedaan, dan kelancaran. Jenis membaca ini bertujuan untuk melatih keterampilan siswa dalam memahami teks berita dengan cara mengidentifikasi dan membacakan teks berita dengan intonasi yang tepat serta artikulasi dan volume suara yang jelas untuk orang lain. Selain itu, untuk mengembangkan potensi mereka dalam bidang ketatabahasaan, memberikan kepercayaan diri dan melatih mereka dalam berbicara maupun berkomunikasi dengan baik dan lancar. Oleh karena itu, penelitian ini penting dilakukan untuk memperoleh informasi tentang kemampuan siswa dalam membacakan 
teks berita dan mengangkat kompetensi dasar membaca teks berita dengan intonasi yang tepat serta artikulasi dan volume suara yang jelas.

Berdasarkan persoalan inilah, penulis tertarik untuk melakukan penelitian dengan judul "Kemampuan Membacakan Teks Berita pada Pembelajaran Siswa Kelas VIII 1 SMP Negeri 3 Kota Bengkulu".

\section{METODE}

Metode dalam penelitian ini ialah metode deskriptif kuantitatif. Penggunaan metode deskriptif kuantitatif ini dimaksudkan untuk mendeskripsikan mulai dari pengumpulan data sampai dengan menyimpulkan hasil penelitian yang terkait dengan kemampuan membacakan teks berita oleh siswa, waktu penelitian ini dilakukan pada semester genap Tahun Ajaran 2016/2017. Populasi dalam penelitian ini adalah semua siswa kelas VII SMP Negeri 1 Bermani llir Tahun Ajaran 2016/2017 yang berjumlah 151 orang. Dalam penelitian ini, peneliti megambil $14 \%$ dari jumlah populasi yang ingin diteliti, sehingga sampel dalam penelitian ini berjumlah 22 orang.

\section{HASIL DAN PEMBAHASAN}

Berdasarkan data yang telah terkumpul, hasil penelitian ini berbentuk skor kemampuan membacakan teks berita pada siswa kelas VIII 1 SMPN 3 Kota Bengkulu tahun ajaran 2016/2017 yang telah dibacakan oleh siswa. Data kemampuan membacakan teks berita hasilnya akan di uraikan berdasarkan masing-masing aspek kemampuan membacakan teks berita. Data tersebut terdiri dari 5 aspek yaitu, kemampuan membacakan teks berita dari aspek intonasi, kemampuan membacakan teks berita dari aspek pelafalan, kemampuan membacakan teks berita dari aspek volume suara, kemampuan membacakan teks berita dari aspek penjedaan, kemampuan membacakan teks berita dari aspek kelancaran.

Kemampuan Membacakan Teks Berita pada Siswa Kelas VIII1 SMP Negeri 3 Kota Bengkulu Tahun Ajaran 2016/2017.

Berdasarkan hasil analisis data kemampuan membacakan teks berita pada siswa kelas VIII 1 SMPN 3 Kota Bengkulu tahun ajaran 2016/2017 dikategorikan kurang. Karena skor akhir yang diperoleh sebesar 55,2 dan apabila dimasukan ke dalam rentang skor skala lima maka berada pada rentang skor 45-55. Kemampuan membacakan teks berita pada siswa kelas VIII 1 SMPN 3 Kota Bengkulu tahun ajaran 2016/2017 terbagi atas: tidak ada siswa (0 \%) dengan kategori nilai sangat baik, 1 orang siswa (5\%) dengan kategori nilai baik, 8 orang siswa (40\%) dengan kategori nilai cukup, 10 orang siswa (50 \%) termasuk dalam kategori kurang, dan 1 orang siswa (5\%) termasuk dalam kategori sangat kurang.

a. Kemampuan Membacakan Teks Berita pada Aspek Intonasi

Berdasarkan hasil analisis data, diketahui bahwa kemampuan membacakan teks berita pada siswa kelas VIII 1 SMPN 3 Kota Bengkulu tahun ajaran 2016/2017 pada aspek intonasi dikategorikan cukup. Rata-rata yang diperoleh sebesar 11,575 dan apabila dilihat pada pada kriteria penilaian aspek kesesuaian intonasi termasuk dalam kategori kurang, karena terletak pada interval nilai 9-12, terbagi atas: tidak ada siswa (0\%) termasuk dalam kategori nilai sangat baik, 7 orang siswa (35\%) termasuk dalam kategori baik, 12 orang siswa (60\%) termasuk kategori cukup, 1 orang siswa (5\%) termasuk kategori kurang, dan tidak ada siswa (0\%) dalam kategori sangat kurang.

b. Kemampuan Membacakan Teks Berita pada Aspek Pelafalan 
Berdasarkan hasil analisis data, diketahui bahwa kemampuan membacakan teks berita pada siswa kelas VIII 1 SMPN 3 Kota Bengkulu tahun ajaran 2016/2017 pada aspek pelafalan dikategorikan cukup. rata yang diperoleh sebesar 10,5 dan apabila dilihat pada pada kriteria penilaian aspek kesesuaian pelafalan termasuk dalam kategori cukup, karena terletak pada interval nilai 9-12, terbagi atas: tidak ada siswa (0\%) termasuk dalam kategori nilai sangat baik, 7 orang siswa (35\%) termasuk dalam kategori baik, 11 orang siswa (55\%) termasuk kategori cukup, 2 orang siswa (10\%) termasuk kategori kurang, dan tidak ada siswa (0\%) dalam kategori sangat kurang.

c. Kemampuan Membacakan Teks Berita pada Aspek Volume Suara

Berdasarkan hasil analisis data, diketahui bahwa kemampuan membacakan teks berita pada siswa kelas VIII 1 SMPN 3 Kota Bengkulu tahun ajaran 2016/2017 pada aspek volume suara dikategorikan cukup. rata yang diperoleh sebesar 11,75 dan apabila dilihat pada pada kriteria penilaian aspek kesesuaian volume suara termasuk dalam kategori cukup, karena terletak pada interval nilai 9-12, terbagi atas: 1 orang siswa (5\%) termasuk dalam kategori nilai sangat baik, 4 orang siswa (20\%) termasuk dalam kategori baik, 12 orang siswa (60\%) termasuk kategori cukup, 3 orang siswa (15\%) termasuk kategori kurang, dan tidak ada siswa (0\%) dalam kategori sangat kurang.

d. Kemampuan Membacakan Teks Berita pada Aspek Penjedaan

Berdasarkan hasil analisis data, diketahui bahwa kemampuan membacakan teks berita pada siswa kelas VIII 1 SMPN 3 Kota Bengkulu tahun ajaran 2016/2017 pada aspek Penjedaan dikategorikan cukup. rata yang diperoleh sebesar 10,2 dan apabila dilihat pada pada kriteria penilaian aspek kesesuaian penjedaan termasuk dalam kategori cukup, karena terletak pada interval nilai 9-12, terbagi atas: tidak ada siswa (0\%) termasuk dalam kategori nilai sangat baik, 2 orang siswa (10\%) termasuk dalam kategori baik, 13 orang siswa (65\%) termasuk kategori cukup, 5 orang siswa (25\%) termasuk kategori kurang, dan tidak ada siswa (0\%) dalam kategori sangat kurang.

e. Kemampuan Membacakan Teks Berita pada Aspek Kelancaran

Berdasarkan hasil analisis data, diketahui bahwa kemampuan membacakan teks berita pada siswa kelas VIII 1 SMPN 3 Kota Bengkulu tahun ajaran 2016/2017 pada aspek kelancaran dikategorikan cukup. rata yang diperoleh sebesar 10,5 dan apabila dilihat pada pada kriteria penilaian aspek kesesuaian kelancaran termasuk dalam kategori cukup, karena terletak pada interval nilai 9-12, terbagi atas: 1 tidak ada siswa (0\%) termasuk dalam kategori nilai sangat baik, 3 orang siswa (15\%) termasuk dalam kategori baik, 12 orang siswa (60\%) termasuk kategori cukup, 5 orang siswa (25\%) termasuk kategori kurang, dan tidak ada siswa (0\%) dalam kategori sangat kurang.

\section{PENUTUP \\ Kesimpulan}

Berdasarkan dari analisis penelitian dan pembahasan, dapat disimpulkan bahwa hasil kemampuan membacakan teks berita pada siswa kelas VIII 1 SMPN 3 Kota Bengkulu diperoleh nilai rata-rata sebesar 57,857 termasuk dalam kategori kurang, karena siswa masih kesulitan membacakan teks berita dengan ketepatan yang baik.Hasil analisis kemampuan membaca teks berita pada siswa kelas VIII 1 SMPN 3 Kota Bengkulu tahun ajaran 2016/2017 berdasarkan masing-masing aspek dapat disimpulkan sebagai berikut: 
1. Pada aspek intonasi kemampuan membaca teks berita pada siswa kelas VIII 1 SMPN 3 Kota Bengkulu tahun ajaran 2016/2017 mendapatkan hasil 11,575 dengan kriteria baik.

2. Pada aspek pelapalan kemampuan membaca teks berita pada siswa kelas VIII 1 SMPN 3 Kota Bengkulu tahun ajaran 2016/2017 mendapatkan hasil 10,5 dengan kriteria baik.

3. Pada aspek volume suara kemampuan membaca teks berita pada siswa kelas VIII 1 SMPN 3 Kota Bengkulu tahun ajaran 2016/2017 mendapatkan hasil 11,75 dengan kriteria baik.

4. Pada aspek penjedaan kemampuan membaca teks berita pada siswa kelas VIII 1 SMPN 3 Kota Bengkulu tahun ajaran 2016/2017 mendapatkan hasil 10,2 dengan kriteria baik.

5. Pada aspek kelancaran kemampuan membaca teks berita pada siswa kelas VIII 1 SMPN 3 Kota Bengkulu tahun ajaran 2016/2017 mendapatkan hasil 10,5 dengan kriteria baik.

\section{Saran}

Berdasarkan hasil penetian yang dilakukan, penulis menyampaikan beberapa saran yang berkaitan dengan dengan penelitian ini, sebagai berikut.

1. Bagi siswa, hendaknya lebih banyak membaca materi dan contoh teks berita untuk menambah kosa kata, wawasan serta pengetahuan mengenai membaca teks berita. Selain itu, siswa hendaknya lebih belajar dan membaca mengenai keterbacaan.

2. Bagi guru, hendaknya guru menekankan pada pembelajaran mengenai keterbacaan, selain itu guru juga harus banyak memberikan latihan membaca teks berita kepada siswa agar melatih pelafalan siswa dalam membaca.

\section{DAFTAR PUSTAKA}

Nadimah, L. 2011. Peningkatan Keterampilan Membaca Berita dengan Teknik Simuladi pada Siswa VII SMPN 4 Semarang. Semarang: Universitas Negeri Semarang.

Nurhadi. 2016. Teknik Membaca. Jakarta: Bumi Aksara.

Rahim, F. 2015. Pengajaran Membaca di Sekolah Dasar. Padang: Bumi Aksara.

Somad, A. A. 2007. Aktif dan Kreatif Berbahasa Indonesia untuk Kelas. Bandung: Buku BSE.

Suyatno. 2004. Teknik-Teknik Pembelajaran Bahasa dan Sastra. Surabaya: Penerbit SIC. 